
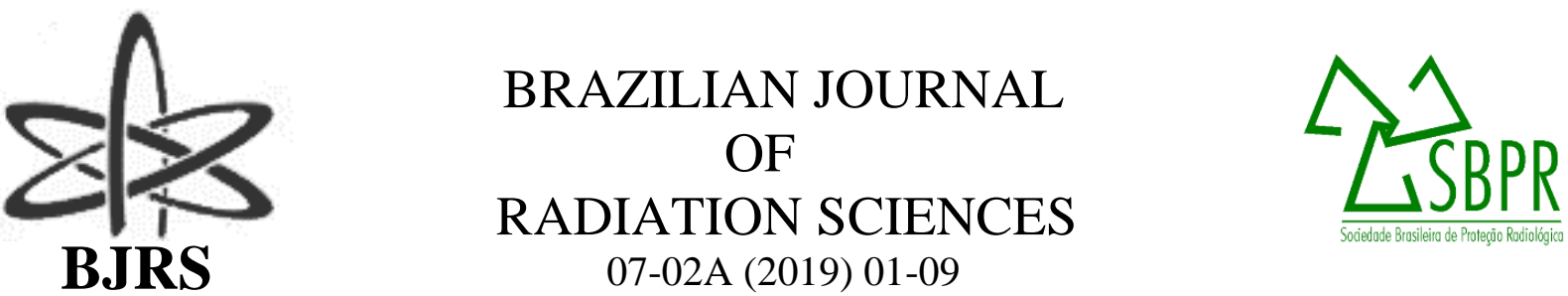

\title{
Natural and artificial nuclides in Salesópolis reservoir
}

\author{
Silva P. S. C., Semmler R., Zahn G. S., Rocha F. R., Damatto S. R., Fávaro D. I. \\ $\mathrm{T}$. \\ Instituto de Pesquisas Energéticas e Nucleares (IPEN / CNEN - SP) \\ Av. Prof. Lineu Prestes, 2242, Cidade Universitária \\ 05508-000 São Paulo, SP \\ pscsilva@ipen.br
}

\begin{abstract}
Natural radioactivity is ubiquitous in the environment mainly due to the presence of the nuclides from the uranium and thorium series and ${ }^{40} \mathrm{~K}$. Although in the South Hemisphere nuclear tests have been fewer in number than that in the North, artificial radionuclides can also be found spread at ground level. In this study, the activity concentrations of natural nuclides from the uranium and thorium series, ${ }^{40} \mathrm{~K}$ and the artificial ${ }^{137} \mathrm{Cs}$ were determined in a sediment core with $42 \mathrm{~cm}$ depth collected in the middle of the Salesópolis reservoir, located in the Metropolitan Region of São Paulo city (SPMR). The Usina Parque Rio Tietê reservoir belongs to the Alto do Tietê system for the capture, storage and treatment of water for SPMR. Therefore, the quality of the water and sediments of this dam is of great importance. The activity concentrations were measured by gamma spectrometry. Samples were measured and saved at regular intervals at a maximum of 160000 seconds. The gross area were determined for each peak and plotted against time and the counting rate was obtained by the slope of the curve. Background and reference materials were also counted and treated in the same way. Results showed that ${ }^{226} \mathrm{Ra}$ varied from 45 to $116 \mathrm{~Bq} \mathrm{~kg}^{-1}$; ${ }^{228} \mathrm{Ra}$, from 80 to $165 \mathrm{~Bq} \mathrm{~kg}^{-1}$; ${ }^{40} \mathrm{~K}$, from 155 to $1187 \mathrm{~Bq} \mathrm{~kg}^{-1}$ and ${ }^{137} \mathrm{Cs}_{\text {varied }}$ from 0.3 to $7 \mathrm{~Bq} \mathrm{~kg}^{-1}$. The methodology applied for determining low levels of ${ }^{137} \mathrm{Cs}$ in sediment proved to be efficient and reproducible.
\end{abstract}

Keywords: Salesópolis, natural radionuclides, artificial radionuclides, reservoir. 


\section{INTRODUCTION}

Environmental radioactivity occurs mainly due to the presence of natural radionuclides of the uranium and thorium series and ${ }^{40} \mathrm{~K}$ in soil, rocks, water and air along with artificial nuclides also spread in the biosphere after nuclear accidents and nuclear weapon tests [1]. Although in the South Hemisphere nuclear tests have been fewer in number than that in the North, artificial radionuclides can also be found spread at ground level $[2,3]$. The distribution of the radionuclides once released in the environment to the different compartments depends on their different geochemical behaviors, as they are subjected to a number of natural processes such as dissolution, adsorption, complexation, and oxidation/reduction.

The natural and man made radionuclides may eventually be accumulated in sediments due to processes like weathering and terrestrial minerals and rocks recycling, rainfall and other depositional phenomena such as gravitational settling and precipitation [4]. Sediments, in turn, can act as sink for these elements or release them to the surrounding water depending on the physical-chemical conditions. This paper aims to evaluate the distribution of the radionuclides belonging to the $U$ and Th series, ${ }^{40} \mathrm{~K}$ and the artificial ${ }^{137} \mathrm{Cs}$ in a sediment core of the Salesópolis reservoir by gamma spectrometry.

Salesópolis is located in the São Paulo city Metropolitan Region (SPMR). The Usina Parque Rio Tietê (Salesópolis) reservoir belongs to the Alto do Tietê system for the capture, storage and treatment of water for the SPMR. Therefore, the quality of the water, as well as of sediments of this dam is of great importance.

\section{MATERIALS AND METHODS}

A sediment core named T1B with $42 \mathrm{~cm}$ depth was collected in the Salesópolis dam in 2.014 with a manual core sampler under a water column of approximately one and a half meters. In the laboratory, the core was sliced each $3 \mathrm{~cm}$ totalizing 14 samples. Each sample was then dried in a ventilated oven at a temperature of $45^{\circ} \mathrm{C}$ and passed in a sieve of $2 \mathrm{~mm}$ aperture. After that, approximately $25 \mathrm{~g}$ of samples were weighted in plastic containers of $5 \mathrm{~cm}$ diameter and $1.5 \mathrm{~cm}$ of 
height, sealed and let to wait at least 30 days for the radioactive equilibrium between ${ }^{226} \mathrm{Ra}$ and its daughters to be reached.

Gamma activity was measured in a EG\&G Ortec spectrometer with relative efficiency of $60 \%$, and resolution of 1.16 and $2.25 \mathrm{keV}$ for the 122 and $1332 \mathrm{keV}$ photopeaks of ${ }^{57} \mathrm{Co}$ and ${ }^{60} \mathrm{Co}$, respectively. In order to diminish the background (BG) contribution the detector is shielded with a sequential layer of lead and copper combined protection.

The activity concentration of ${ }^{226} \mathrm{Ra}$ was determined by the mean activity measurement of its daughter's photopeaks in $351 \mathrm{keV}\left({ }^{214} \mathrm{~Pb}\right), 609$ and $1.120 \mathrm{keV}\left({ }^{214} \mathrm{Bi}\right)$. The activity concentration of ${ }^{228} \mathrm{Ra}$ was determined by the gamma transitions in $338 \mathrm{keV}, 911 \mathrm{keV}\left({ }^{228} \mathrm{Ac}\right), 238 \mathrm{keV}\left({ }^{212} \mathrm{~Pb}\right)$ and $727 \mathrm{keV}\left({ }^{212} \mathrm{Bi}\right)$. Potassium-40 and ${ }^{137} \mathrm{Cs}$ were determined directly by means of their gamma transition photopeaks in $1.460 \mathrm{keV}$ and $661 \mathrm{keV}$, respectively.

The efficiency curve determination was performed by using the reference materials IAEA-RGU (uranium ore diluted with floated silica powder), IAEA-RGTh (thorium ore diluted with floated silica powder), IAEA-K (high purity potassium sulphate) and IAEA-375 (radionuclides and trace elements in soil) in the same geometry as the samples for the same gamma transitions photopeaks to be determined. All these reference material have activity sufficiently high to give a statistical error of less than $1 \%$ in the considered counting time. No self-attenuation correction was applied since the energy of all determined nuclides was higher than $200 \mathrm{keV}$.

For the data acquisition, the processing software was programmed to save the counting files from $100000 \mathrm{~s}$ to $160000 \mathrm{~s}$ in intervals of $10000 \mathrm{~s}$. A background measurement was also done intercalating each two samples counting. This BG counts was subtracted from the samples counting [5].

For each sample and respective BG a plot of gross counts per time was generated to obtain the curve slope. Figures 1 and 2 exemplify the procedure for ${ }^{137} \mathrm{Cs}$ determination and that was then repeated for each radionuclide to be determined. tion 1 .

Calculation of the activity concentration was done according to the formula presented in equa-

$$
A_{i}=\frac{C_{i}-C_{b g i}}{m_{a} x \varepsilon_{i}}
$$

where:

$\mathrm{A}_{i} \quad$ is the activity concentration related to the photopeak $\mathrm{i}\left(\mathrm{Bq} \mathrm{kg}^{-1}\right)$ 
$\mathrm{C}_{i} \quad$ is the slope of the curve obtained for the photopeak $\mathrm{i}$ in the sample

$\mathrm{C}_{b g i}$ is the slope of the curve obtained for the photopeak $\mathrm{i}$ in the background

$\mathrm{m}_{a} \quad$ is the sample mass $(\mathrm{kg})$

$\varepsilon_{i} \quad$ is the counting efficiency for the photopeak of interest.

Figure 1: Plot of the background counts per time (in seconds) in the $661 \mathrm{keV}$ region of interest

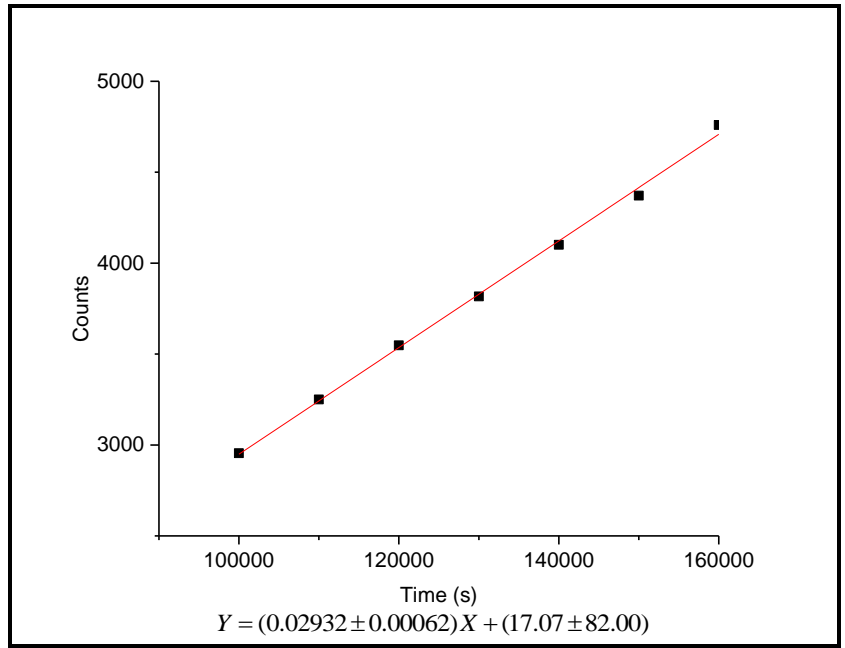

Figure 2: Plot of the counts per time (in seconds) in the $661 \mathrm{keV}$ region of interest for a given sample

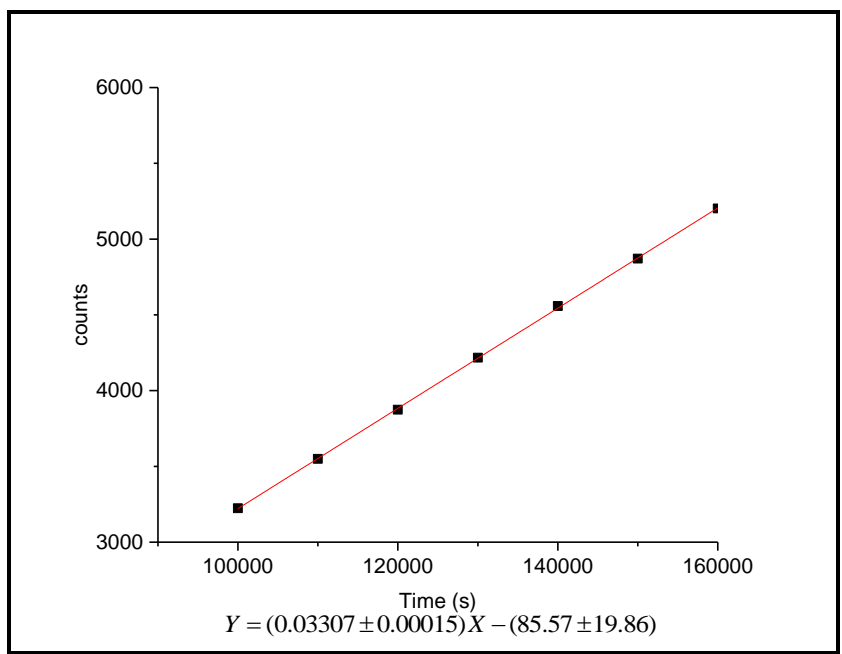


The uncertainties were determined by error propagation, with the uncertainties of $\mathrm{C} i$ and $\mathrm{C}_{b g i}$ being that obtained from the slope of the adjusted curve for each photopeak considered.

\section{RESULTS AND DISCUSSION}

Table 1 shows the activity concentration measured in the reference material IAEA-414, IAEA-SD-N-2 and IAEA-375 and it is possible to see the good agreement between the measured values and the certified ones.

Table1: Results obtained for the reference materials IAEA-327, IAEA-414 and IAEA-SD-N-2, in $\mathrm{Bq} \mathrm{kg}^{-1}$ (recommended values in parenthesis).

\begin{tabular}{lccc}
\hline & $\begin{array}{c}\text { Reference ma- } \\
\text { terial }\end{array}$ & $\begin{array}{l}\text { Obtained } \\
\text { value }\end{array}$ & $\begin{array}{c}\text { recommended } \\
\text { value }\end{array}$ \\
\hline${ }^{\mathbf{2 2 6}} \mathbf{R a}$ & IAEA-327 & $43 \pm 8$ & $38.7 \pm 5.2$ \\
\hline${ }^{\mathbf{2 2 8}} \mathbf{R a}$ & IAEA-327 & $40 \pm 7$ & $38.7 \pm 4.7$ \\
\hline${ }^{\mathbf{4 0}} \mathbf{K}$ & IAEA-327 & $641 \pm 41$ & $621 \pm 52$ \\
& IAEA-414 & $406 \pm 26$ & $481 \pm 16.5$ \\
& IAEA-SD-N-2 & $218 \pm 14$ & $220 \pm 16$ \\
\hline${ }^{\mathbf{1 3 7}} \mathbf{C s}$ & IAEA-327 & $28 \pm 7$ & $24.9 \pm 1.8$ \\
& IAEA-414 & $5 \pm 1$ & $5.18 \pm 0.1$ \\
& IAEA-SD-N-2 & $0.9 \pm 0.2$ & $0.8 \pm 0.5$ \\
\hline
\end{tabular}

\subsection{Natural radionuclides}

Table 2 presents the values of the determined radionuclides in the samples obtained in the analyzed core. It is possible to see that radium isotopes are in higher concentrations than that reported for the global soil average [6] of $32 \mathrm{~Bq} \mathrm{~kg}^{-1}$ for ${ }^{226} \mathrm{Ra}$ and $45 \mathrm{~Bq} \mathrm{~kg}^{-1}$ for ${ }^{228} \mathrm{Ra}$ (considered in equilibrium with ${ }^{232} \mathrm{Th}$ ). For ${ }^{40} \mathrm{~K}$, only the first $12 \mathrm{~cm}$ are below the global average of $420 \mathrm{~Bq} \mathrm{~kg}^{-1}$ [6] and the activity concentrations tend to rise with the depth.

Figure 3 shows that the radium isotopes have almost the same behavior with depth, with the lowest values observed between 9 and $12 \mathrm{~cm}$ depth. Higher activity concentrations were also observed for both nuclides in the base of the core. Nevertheless, ${ }^{228} \mathrm{Ra}$ tend to be enriched over ${ }^{226} \mathrm{Ra}$ in the top layers with the enrichment being less pronounced towards the core base as depicted by 
the ${ }^{228} \mathrm{Ra} /{ }^{226} \mathrm{Ra}$ ratio showed in Figure 4 probably indicating a change in the sediment source and mineralogy.

Few data are available on the activity concentrations of natural radionuclides in Brazilian reservoirs. Concentrations lower than those observed in this study, around $20 \mathrm{~Bq} \mathrm{~kg}^{-1}$, were determined for ${ }^{226} \mathrm{Ra}$ in the Apipucos Reservoir, Recife, Brazil [7]. In sediments of Cubatão river, ${ }^{226} \mathrm{Ra}$ activity concentration varied in the range of 28 to $80 \mathrm{~Bq} \mathrm{~kg}^{-1}$ [8] and the activity concentrations of ${ }^{226} \mathrm{Ra}$ and ${ }^{228} \mathrm{Ra}$ were in the range of 26 to $37 \mathrm{~Bq} \mathrm{~kg}^{-1}$ and 59 to $74 \mathrm{~Bq} \mathrm{~kg}^{-1}$, respectively [9]. Considering aquatic environments with saline water, levels of ${ }^{238} \mathrm{U}\left({ }^{226} \mathrm{Ra}\right),{ }^{232} \mathrm{Th}$ and ${ }^{40} \mathrm{~K}$ of 21,28 and $426 \mathrm{~Bq}$ $\mathrm{kg}^{-1}$ were determined [10] in the shelf and upper slope of Southeast Brazil. Also levels of ${ }^{226} \mathrm{Ra}$ in the range of 4.2 to 28.5 were determined in the Cananéia- Iguape system [11]. Mean activity concentrations of $24 \mathrm{~Bq} \mathrm{~kg}^{-1}$ for ${ }^{226} \mathrm{Ra}, 44 \mathrm{~Bq} \mathrm{~kg}^{-1}$ for ${ }^{232} \mathrm{Th}$ and $678 \mathrm{~Bq} \mathrm{~kg}{ }^{-1}$ for ${ }^{40} \mathrm{~K}$ were found in the Piraquara de Fora Inlet located in Ribeira Bay within the Ilha Grande Bay in Angra dos Reis, Rio de Janeiro State [3]. It can be seen that the values obtained in this study for the Salesópolis reservoir are generally higher that those reported in literature and that sediments of salty waters generally presents lower activity concentrations.

Table 2: Activity concentrations, in $\mathrm{Bq} \mathrm{kg}^{-1}$, of measured radionuclides in the sediment core samples.

\begin{tabular}{ccccc}
\hline Depth (cm) & ${ }^{\mathbf{2 2 6}} \mathbf{R a}$ & ${ }^{\mathbf{2 2 8}} \mathbf{R a}$ & ${ }^{\mathbf{4 0}} \mathbf{K}$ & ${ }^{\mathbf{1 3 7}} \mathbf{C s}$ \\
\hline $0-3$ & $74 \pm 13$ & $126 \pm 31$ & $300 \pm 19$ & $5 \pm 1$ \\
$3-6$ & $67 \pm 12$ & $132 \pm 33$ & $155 \pm 10$ & $2 \pm 1$ \\
$6-9$ & $72 \pm 13$ & $105 \pm 26$ & $272 \pm 17$ & $7 \pm 3$ \\
$9-12$ & $45 \pm 8$ & $80 \pm 20$ & $179 \pm 11$ & $0.3 \pm 0.1$ \\
$12-15$ & $67 \pm 12$ & $113 \pm 20$ & $680 \pm 43$ & $3 \pm 1$ \\
$15-18$ & $79 \pm 14$ & $133 \pm 33$ & $807 \pm 52$ & $4 \pm 2$ \\
$18-21$ & $65 \pm 11$ & $108 \pm 27$ & $856 \pm 55$ & $3 \pm 1$ \\
$21-24$ & $72 \pm 13$ & $116 \pm 29$ & $843 \pm 54$ & $3 \pm 1$ \\
$24-27$ & $70 \pm 12$ & $103 \pm 26$ & $830 \pm 53$ & $4 \pm 2$ \\
$27-30$ & $79 \pm 11$ & $122 \pm 30$ & $978 \pm 63$ & $4 \pm 2$ \\
$30-33$ & $83 \pm 14$ & $130 \pm 32$ & $1026 \pm 66$ & $4 \pm 2$ \\
$33-36$ & $75 \pm 13$ & $122 \pm 30$ & $940 \pm 60$ & $4 \pm 2$ \\
$36-39$ & $89 \pm 15$ & $124 \pm 31$ & $950 \pm 61$ & $5 \pm 2$ \\
$39-42$ & $116 \pm 20$ & $165 \pm 41$ & $1187 \pm 76$ & $4 \pm 2$ \\
\hline
\end{tabular}

Table 3 shows a compilation of activity concentrations for radium isotopes, ${ }^{40} \mathrm{~K}$ and ${ }^{137} \mathrm{Cs}$, found in sediments of reservoirs located in North Hemisphere. For the natural radionuclides it can be seen 
that the levels are closer to those observed for the global average [6] and present a mean narrower those observed for the Brazilian reservoir and the results obtained in this work.

Higher activity concentrations for natural radionuclides may be related to geological and geochemical conditions such as the rock and soil basement and leaching by an intense rainfall system.

Figure 3: Distribution of ${ }^{226} \mathrm{Ra}$ and ${ }^{228} \mathrm{Ra}$ with the depth in the analyzed core

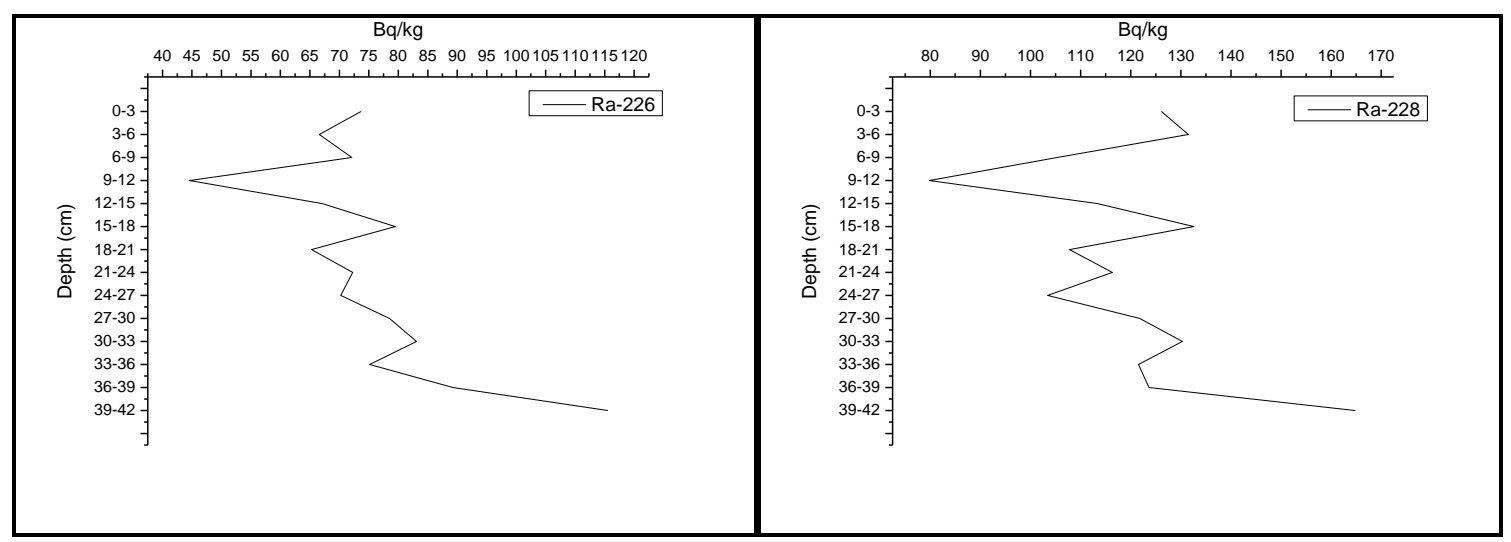

Figure 4: Distribution of ${ }^{228} \mathrm{Ra}{ }^{226} \mathrm{Ra}$ isotopic ratio with depth

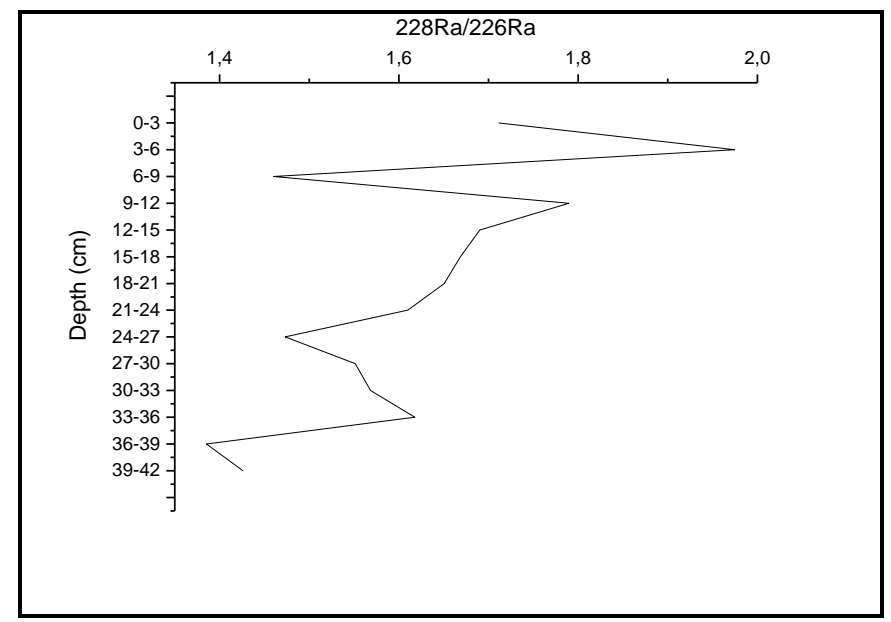

\subsection{Artificial radionuclide ${ }^{137} \mathrm{Cs}$}

The distribution of ${ }^{137} \mathrm{Cs}$ with depth is shown is Figure 5. The lowest activity concentration was observed at $9-12 \mathrm{~cm}$ depth and the highest was determined in the range of 6 to $9 \mathrm{~cm}$, although it is 
unlikely that this peak corresponds to the maximum fallout of Cs. The observed variation in the top layers may be related to the grain size and organic matter distribution [18].

The most probable peak of ${ }^{137} \mathrm{Cs}$ activity concentration corresponding to the fallout of 19631964 can be observed in the depth of $36-39 \mathrm{~cm}$. As for the natural radionuclides, few activity concentrations were reported for ${ }^{137} \mathrm{Cs}$ in reservoir sediments.

Table 3: Activity concentrations, in $\mathrm{Bk} \mathrm{kq}^{-1}$, of natural and artificial radionuclides in sediment samples of reservoirs form selected locations in the North Hemisphere.

\begin{tabular}{lllrlr}
\hline & ${ }^{226} \mathbf{R a}$ & ${ }^{\mathbf{2 2 8}} \mathbf{R a}$ & ${ }^{\mathbf{4 0}} \mathbf{K}$ & ${ }^{\mathbf{1 3 7}} \mathbf{C s}$ & Reference \\
\hline Spain & $58-94$ & $59-116$ & $535-823$ & $1.7-60.2$ & {$[12]$} \\
India & $4-26$ & $5.5-19.9$ & $250-558$ & $3.6-54.5$ & {$[13]$} \\
Tunisia & $23-29.8$ & $40-52$ & & $0.9-3.9$ & {$[14]$} \\
Serbia & $8-29$ & $2.7-45$ & & $0.8-140$ & {$[15]$} \\
China & $31.2-37.5$ & $56.5-79.8$ & $179.4-214.9$ & & {$[16]$} \\
Poland & & & & $89-865$ & {$[17]$} \\
Poland & & & $30-243$ & {$[18]$} \\
Turkey & & & $1-101$ & {$[19]$} \\
\hline
\end{tabular}

Figure 5: Distribution of ${ }^{137} \mathrm{Cs}$ with the depth in the analyzed core

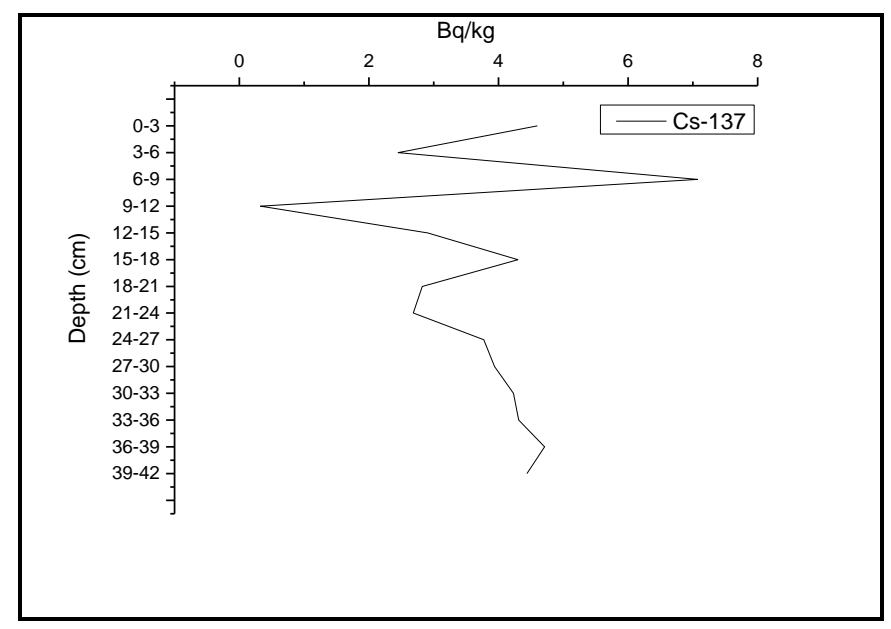

Considering Brazilian sediment of other aquatic environments, levels of this radionuclide in the range of 0.2 to $6.1 \mathrm{~Bq} \mathrm{~kg}^{-1}$ were found in the Cananéia-Iguape system [11]; activity concentration of $0.5 \pm 0.2 \mathrm{~Bq} \mathrm{~kg}^{-1}$ for ${ }^{137} \mathrm{Cs}$ was determined in the Piraquara de Fora Inlet [3]; values around $3 \mathrm{~Bq}$ $\mathrm{kg}^{-1}$ were found in the sediments of Guajará Bay, in Pará State [2] and a maximum of $4.7 \mathrm{~Bq} \mathrm{~kg}^{-1}$ 
was reported [20] for the Brazilian cost. The values obtained in this study are in good agreement with those observed in the references cited above, and all the highest values found in Brazilian sediments were much lower than those found in the North Hemisphere, as shown in Table 3. Closer values to the ones reported here were found in a South African reservoir with activity concentrations around $10 \mathrm{~Bq} \mathrm{~kg}^{-1}$ [21].

\section{CONCLUSIONS}

The methodology applied for determining low levels of ${ }^{137} \mathrm{Cs}$ in sediment proved to be efficient and reproducible. The levels of natural radionuclides found in the sediment core of Salesópolis dam are higher than the world average. These activities can be related to the local geochemistry associated with intense rainfall. Results showed a tendency of raising values in the core base possibly indicating a variation in the mineralogical features as shown by the decrease in the ${ }^{228} \mathrm{Ra} /{ }^{226} \mathrm{Ra}$ ratio.

The activity concentrations of ${ }^{137} \mathrm{Cs}$ present a great variation in the upper layers probably related to the granulometry distribution and organic matter content. The values found are in accordance with the ones observed for other Brazilian aquatic environments. Nevertheless, more studies are necessary to better understand the observed variation as well as the hole of local conditions in the observed values.

\section{ACKNOWLEDGMENT}

Authors are thankful to the Fundação de Amparo à Pesquisa do Estado de São Paulo - FAPESP - for the financial support (FAPESP Process n ${ }^{0}:$ 2014/20805-6).

\section{REFERENCES}

1. IAEA. Radiation, People and Environment. International Atomic Energy Agency, Viena, Austria, (2004).

2. FERREIRA, P. A. L., NEVES, P. A., FIGUEIRA, R. C. L. Evaluation of recent sedimentation rates in Guajará Bay (in Brasilina cost) with $210 \mathrm{~Pb}$ and $137 \mathrm{Cs}$. International Nuclear Atlantic Conference - INAC 2013, Recife, PE, Brazil, November 24 - 29, (2013). 
3. CARVAlHO, F. M., LAURIA, D. C., RIBEIRO, F. C. A., FONSECA, R. T., PERES, S. S., MARTINS, N. S. F. "Natural and man-made radionuclides in sediments of an inlet in Rio de Janeiro State, Brazil”, Marine Pollution Bulletin, 107, pp. 269 - 276 (2016).

4. CARIDI, F., MARGUCCIO, S., BELVEDERE, A., BELMUSTO, G. "Measurements of Gamma Radioactivity in River Sediment Samples of the Mediterranean Central Basin”, J Phys Condens Matter, 5(3), pp. 61- 68 (2015).

5. FIGUEIRA, R. C. L., SILVA, R. L. N., FIGUEIREDO, A. M. G., CUNHA, I. I. L. Instrumental analysis by gamma spectrometry of low level caesium-137 in marine samples. Proceedings of an International Conference, Goiania, Brazil, 26 - 31 octouber, pp. 329 - 337 (1997).

6. UNSCEAR. Sources and Effects of Ionizing Radiation. Volume I: Effects. UNSCEAR 2008 Report. United Nations Scientific Committee on the Effects of Atomic Radiation, Report to the General Assembly, with scientific annexes. United Nations sales publication E.00.IX.4. United Nations, New York (2010).

7. SOUZA, V. L. B., RODRIGUES, K. R. G., PEDROZA, E. H., MELO, R. T., LIMA, V. L., HAZIN, C. A., ALMEIDA, M. G. O., NASCIMENTO, R. K. "Sedimentation Rate and 210Pb Sediment Dating at Apipucos Reservoir, Recife, Brazil”, Sustainability, 4, pp. 2419 - 2429 (2012).

8. SANDERS, L. M., SANDERS, C. J., LUIZ-SILVA, W., MACHADO, W., SILVA-FILHO, E. V., PATCHINEELAM, S. R. "Anthropogenic source assessment of $226 \mathrm{Ra}$ and $210 \mathrm{~Pb}$ in a sediment core from the Cubatão River estuary (SE Brazil)”, J Radioanal Nucl Chem, 287(3), pp. 729 732 (2011).

9. SILVA, P. S. C., MAZZILli, B. P., FÁVARO, D. I. T. "Distribution of radionuclides and elements in Cubatão River sediments”, J Radioanal Nucl Chem, 269 (3), pp. 767 - 771 (2006).

10. CORDERO, L. M., FIGUEIRA, R. C. L., MAHIQUES, M. M., TESSLER, M. G. "Natural radionuclides distribution in the shelf and upper slope off Southeast Brazil". International Nuclear Atlantic Conference - INAC, Rio de Janeiro,RJ, Brazil, September 27 to October 2, pp. $1-7$ (2009).

11. SAITO, R. T. Radionuclídeos $\left({ }^{210} \mathrm{~Pb},{ }^{226} \mathrm{Ra},{ }^{210} \mathrm{Po}\right.$ e $\left.{ }^{137} \mathrm{Cs}\right)$ no sistema costeiro CanaéiaIguape: estudos ambientais. Doctorate Thesis IPEN, (2002). (in portuguese). 
12. BAEZA, A., GUILlÉN, J., ONTALBA SALAMANCA, M. A., RODRÍGUEZ, A., AGER, F. J. "Radiological and multi-element analysis of sediments from the Proserpina reservoir (Spain) dating from Roman times”, J Environ Radioact, 100, pp. 866 - 874 (2009).

13. SUGANDHI, S., JOSHI, V. M., RAVI, P. M. "Studies on natural and anthropogenic radionuclides in sediment and biota of Mumbai Harbour Bay”, J Radioanal Nucl Chem, 300, pp. 67 70 (2014).

14. SLIMANE, A. B., RACLOT, D., EVRARD, O., SANAA, M., LEFÈVRE, I., AHMADI, M., TOUNSI, M., RUMPEL, C., MAMMOU, A. B., BISSONNAIS, Y. "Fingerprinting sediment sources in the outlet reservoir of a hilly cultivated catchment in Tunisia”, J Soils Sediments, 13, pp. 801 - 815 (2013).

15. TOŠIĆ, R., TODOROVIĆ, D. J., DRAGIĆEVIĆ, S. S., BIKIT, I. S., FORKAPIĆ, S., BLAGOJEVIĆ, B. "Radioactivity and measurements of sediment deposition rate of the Drenova Reservoir (B\&H)”, Nuclear Technology \& Radiation Protection, 27 (1), pp. 52 - 56 (2012).

16. LU, X., PAN, H., REN, C., YANG, L. "Natural radioactivity in reservoir sediment near an industrial park of northwest China”, J Radiol Prot, 36, pp. N26 - N33 (2016).

17. SZARLOWICZ, K., RECZYNSKI, W., MISIAK, R., KUBICA, B. "Radionuclides and heavy metal oncentrations as complementary tools for studying the impact of industrialization on the environment", J Radioanal Nucl Chem, 298, pp. 1323 - 1333 (2013).

18. SZARLOWICZ, K., KUBICA, B. “137 $\mathrm{Cs}$ and ${ }^{210} \mathrm{~Pb}$ radionuclides in open and closed water ecosystems", J Radioanal Nucl Chem, 299, pp. 1321 - 1328 (2014).

19. KUILAHCIA, F., ŞEN, Z. "Multivariate statistical analyses of artificial radionuclides and heavy metals contaminations in deep mud of Keban Dam Lake, Turkey”, Appl Radiat Isot, 66, 236 - 246 (2008).

20. SANTOS, I. R., BURNETT, W. C., GODOY, J. M. "Radionuclides as tracer of coastal processes in Brazil: review, synthesis, and perspectives”, Braz J Oceanogr, 56(2), 115 - 131, (2008).

21. FOSTER, I. D. L., BOARDMAN, J., KEAY-BRIGHT, J. "Sediment tracing and environmental history for two small catchments, Karoo Uplands, South Africa”, Geomorphology, 90, 126 - 143 (2007). 